\title{
Eco-Friendly Applications of Bacterial Extracellular Alkaline Protease
}

\author{
More S. $\mathrm{Y}^{1}$, Bholay A. D ${ }^{2}$, Nalawade P.M ${ }^{1}$ \\ ${ }^{I}$ Department of Environmental science, K.T.H.M College, Nashik, SPP University, Pune M.S \\ ${ }^{2}$ P.G.Dept of Microbiology, K.T.H.M College, Nashik, SPP University, Pune, M.S
}

\begin{abstract}
Among the most important hydrolytic enzymes microbial alkaline protease have been extensively used since the advent of enzymology. It is produce by bacterium either extracellular or intracellular. Isolation and screening of sufficient extracellular alkaline protease producing bacterial strains are of great importance due to its wide spectrum applications in number of industries such as bio-remediation, food industries, leather processing, bio-film degradation, keratin degradation antifungal activity and number of other eco-friendly applications. The various samples, sea water, domestic water sludge, fish market soil and fermented fish were collected and used for enrichment, isolation and screening was done using screening medium and optimization for different physical and chemical parameters were carried out using CYP agar medium.

Out of 18 isolates 16 were alkaline protease positive out of those; 4 isolates were able to produce sufficient amount of extracellular alkaline protease. The ratio of zone diameter to colony diameter from 4 isolates ranges from 3.11 to 8.41. Out of four efficient alkaline protease producers B.pumilus P1 showed significant enzyme activity. Optimizations of physical parameters were determined and found to be 72 hours of incubation period, 8.0 to $9.0 \mathrm{pH}, 45^{\circ} \mathrm{C}$ incubation period. Optimization of chemical parameters were determined for variety of carbon and nitrogen sources, were found to be $1.5 \%$ of glucose, lactose, $2 \%$ of sucrose, $0.7 \%$ of ammonium sulphate, gelatin in case of refined sources. Wheat bran, sugarcane baggase as carbon sources and soya bean meal, cotton stalk gave maximum enzyme activity at 10\% concentration. Enzyme obtained from refined sources and crude sources having maximum enzyme activity $16.5 \mathrm{U} / \mathrm{ml}$ and $8.3 \mathrm{U} / \mathrm{ml}$ respectively.

Crude as well as partially purified enzyme preparations were found to be excellent in dehairing, depilation, of raw leather, degradation of feather, bio-film degradation and antifungal activity.
\end{abstract}

Keywords: Alkaline protease, Leather processing, Antifungal, Insecticidal, Bio-film, B.pumilus

\section{Introduction}

Proteases are the enzymes occur anywhere in nature. They are found to be inside or on the surface of the organism ${ }^{1}$. Proteases break down protein by hydrolysis of peptide bond that exists between two amino acids of polypeptide chain. Today proteases available in the market are derived from microbial source ${ }^{2}$.

Proteases are classified according to their active $\mathrm{pH}$ range in to Neutral, Acidic and alkaline. Proteases from marine microbes are currently receiving increasing attention due to their inherent stability at different values of $\mathrm{pH}$, temperature and salinity ${ }^{3,4,5}$.

Proteases are having number of environmentally friendly applications. It can substitute number of chemical fungicides ${ }^{6}$, insecticides in agriculture ${ }^{6}$, dehairing agents in leather processing ${ }^{8,9}$, it removes bio-film very efficiently ${ }^{4}$, control water and soil pollution.

Proteolytic enzymes are more efficient in enzymatic dehairing of raw leather than amylolytic enzymes. They are also useful in detergent formulations ${ }^{9}$.

\section{Materials And Methods}

Sample: Soil samples from vicinity of mutton market, fish market, similarly waste water sludge, fermented fish and sea water were used to prepare initial inoculums. ${ }^{2,10}$

Isolation: The sample from different locations inoculated in $100 \mathrm{ml}$ nutrient broth; $\mathrm{pH}$ value ranging from 8-10 and enrichment is carried out for $48 \mathrm{hrs}$ at room temperature under shaking condition. ${ }^{2,10}$

Enriched broth was diluted and spread plated on skimmed milk agar medium consisting of each (\%W/V) skimmed milk powder (5), peptone (0.2) $\mathrm{NaCl}(0.5)$ agar (2) and $\mathrm{pH} \mathrm{8-10.} \mathrm{Plates} \mathrm{were} \mathrm{incubated} \mathrm{at} \mathrm{room}$ temperature and examine for halo around the colonies as the sign of protease producing ability of an organism ${ }^{11}$. Based on zone of casein hydrolysis different isolates were selected and were maintained on agar plats ${ }^{11}$.

Screening: A suitably diluted culture $0.2 \mathrm{ml}$ was spread on casein yeast extract peptone agar medium or on nutrient agar medium with $4 \%$ gelatin was inoculated at $37^{\circ} \mathrm{C}$ for $24 \mathrm{hrs}$; plates were flooded with $1 \%$ tannic acid solution colonies showing clear zone of hydrolysis were picked and purified ${ }^{12}$.

Enzyme activity was calculated as the ratio of diameter of zone of clearance to colony diameter ${ }^{12}$. 
Characterization of bacterial isolates: Bacterial isolates with prominent zone of clearance and showing efficient enzyme production were processed for determination of colony morphology. Gram staining, motility, biochemical test and enzyme profile then identified in accordance with Bergey's manual of determinative bacteriology, further isolates were confirmed by VITEK-2 system version 05.02.

Optimization of physic-chemical parameters: Extracellular alkaline protease production was optimized for various physico-chemical parameters. The production medium CYP was supplemented with different concentration of refined nitrogen sources, carbon sources ${ }^{8}$ and crude nitrogen, carbon sources ${ }^{2,17}$. The various incubation periods were $12,24,48,72$ and 96 hours, Temperature $30,3540,45,50$ and $55^{\circ} \mathrm{C}^{8,9}$, $\mathrm{pH}$ values ranged from 7.5 to $10.5^{13,14}$ and different sodium alginate concentration in case of immobilized cell.

Fermentation experiment was carried out for production of extracellular alkaline protease by isolate Bacillus pumilus $\mathrm{p} 1$. The enzyme was produced by inoculating $2 \%$ culture in to $200 \mathrm{ml}$ production medium in bottled Erlenmeyer flask at its optimized conditions ${ }^{2}$. Enzyme production was carry out using submerged and solid state fermentation using refined and crude sources respectively ${ }^{1,4,20}$.

Estimation of protease was done by standard protease assay.

Preparation of purified enzyme: The culture supernatant obtained by centrifugation of cultured broth at $10,000 \mathrm{rpm}$ for 15 min's at $4^{0} \mathrm{C}$. Ammonium sulphate was added in to culture supernatant and the precipitate is obtained at $60-70 \%$ saturation was collected and dialyzed ${ }^{3,13}$.

Applications of alkaline protease: Dehairing of hide: Goat skin was selected for a study which was washed with water to remove salt and other debris. It was cut in to small pieces which were later treated with enzyme. The skin pieces were treated with either crude enzyme preparation only (Treatment 1); $7 \%$ sodium sulphide,lime and crude enzyme preparation (Treatment 2); and 14\%sodium sulphide and lime(Treatment 3) as positive control $^{8,9}$.

The skin pieces after above treatment were examined for depilation time, depilation extent; pelt color and scud evaluate the process of depilation with different depilating agents. So, the produced crude material was further processed by conventional methods. The finally prepared pieces of leather were also accessed by examining the features such as colour, scud removal and general appearance of the body.

Keratin degradation: Keratin degradation was observed using enzymatic digestion of feather and biological degradation of chicken feathers. In enzymatic digestion feathers were treated with purified enzyme preparation. In biological degradation feathers were directly incubated with isolated microbial cells with negative and positive controls. The use of enzymes in feather meal is an attractive and alternative approach over conventional methods which results in loss of essential amino acids.

The ability of bacillus strain to produce appreciable level of keratinase and protease using feather as substrate could open new opportunities for the achievement of efficient biodegradation. Keratin degradation using microbes helps to reduce environmental impact of chemicals.

Bio-film degradation: Bio-film formation and quantification using glass taste tubes were measured. Overnight culture of E. coli and pseudomonas fluorescence, $0.2 \mathrm{ml}$ inoculated in biofilm growth medium and incubated overnight at $37^{0} \mathrm{C}^{4}$.

To screen for the efficiency of enzyme in removing biofilm; the enzyme treatment was given in two ways such as in the medium during the incubation and after the incubation at $45^{\circ} \mathrm{C}$.

After incubation the growth medium was gently removed by adding $2 \mathrm{ml}$ of cleaning solution $\left(45^{\circ} \mathrm{C}\right.$ water is used as control) and incubated the tubes for 30 minutes. After which the solution was gently pipetted out. Then $2 \mathrm{ml}$ water and $2 \mu \mathrm{l}$ of $1 \%$ crystal violet solution was added in each tube and incubated for 15 minutes. Later tubes were rinsed with normal water. Crystal violet stained bio-film was solubilized in $95 \%$ ethanol and thus formed crystal violet ethanol solution were measured for absorbance at $595 \mathrm{~nm}^{4}$.

Antifungal activity

Test organism: Two fungal plant pathogens were isolated from local soil sample, were grown on potato dextrose agar plates and incubated at $30^{\circ} \mathrm{C}$ for 5 days. The isolated fungal plant pathogen cultured on slants of PDA and preserved for further study ${ }^{19}$.

Pure cultures of fugal plant pathogens were identified as Fusarium solani and Rizoctonia solani according to some cultural properties and morphological characterstic's.

Assay of antifungal activity: Antifungal activity of partially purified protease enzyme against $F$.solani and R.solani was carried out using agar well diffusion technique using $100 \mu 1$ partially purified enzyme. $1 \mathrm{ml}$ of test culture was used for surface inoculation on PDA and antifungal activities were determined after 4 days of incubation at $30^{\circ} \mathrm{C}$ by measuring diameter of developed inhibition zone ${ }^{6}$.

\section{Results And Discussions}

Screening: The isolation and screening of alkaline protease producing bacterial isolates were done on the basis of mean value of zone of gelatin hydrolysis on gelatin agar medium (Table-1). 
Table 1. Screening of efficient alkaline protease producing isolates on the basis of zone of clearance.

\begin{tabular}{|l|l|l|l|}
\hline Isolates & Zone dia(mm) & Colony dia $(\mathbf{m m})$ & Efficiency \\
\hline p1 & $24 \pm 0.8$ & $2 \pm 0.6$ & 12.0 \\
\hline p2 & $28 \pm 1.2$ & $4 \pm 0.5$ & 7.0 \\
\hline p3 & $29 \pm 0.5$ & $7 \pm 0.3$ & 4.1 \\
\hline p4 & $38 \pm 0.3$ & $15 \pm 0.2$ & 2.5 \\
\hline
\end{tabular}

Characterization and identification: The selected isolate was characterized on the basis of morphological, biochemical and enzymatic profile as per Bergey's manual of systematic bacteriology $4^{\text {th }}$ edition. Further the species was identified on VITEK-2 system version 05:02 and confirmed as Bacillus pumilus $\mathrm{p} 1$.

Optimization of physicochemical parameters: The following factors investigated for their effect on protease activity are incubation period, incubation temperature and various $\mathrm{pH}$ values. As well as different refined and crude carbon, nitrogen sources were optimized for enzyme activity. Effect of immobilized cells on enzyme activity was found out using different concentrations of sodium alginate.

Table 2. Identification of alkaline protease producing organism using VITEK 2 system version: 05.02

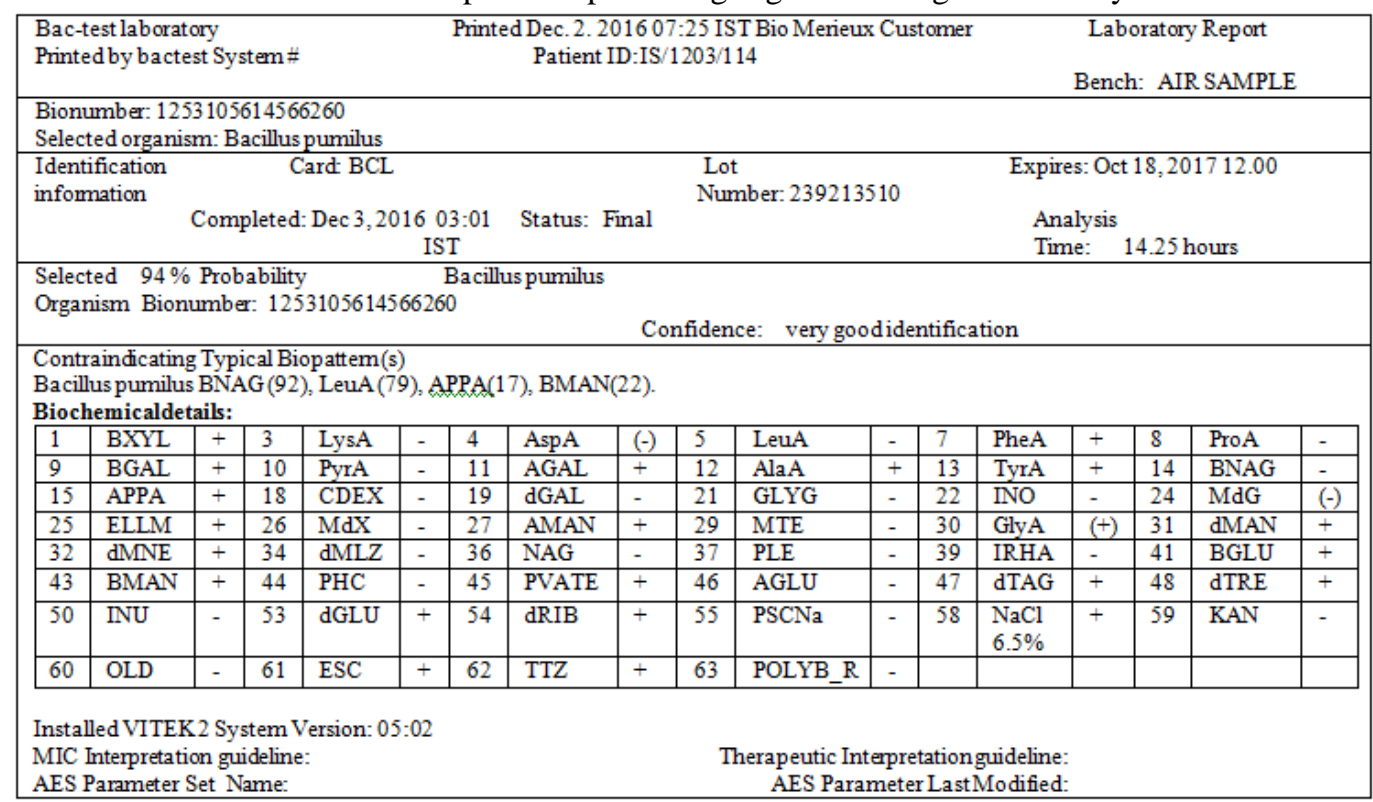

Effect of Incubation period on enzyme production: The maximum biosynthesis of proteases was observed within 72 hours using B.pumilus p1. The production of proteases was proportionally increased with the incubation time within the time range of 12 to 96 hours of incubation, whereas after 72 hours of incubation the protease activity decreased considerably (Figure 1).

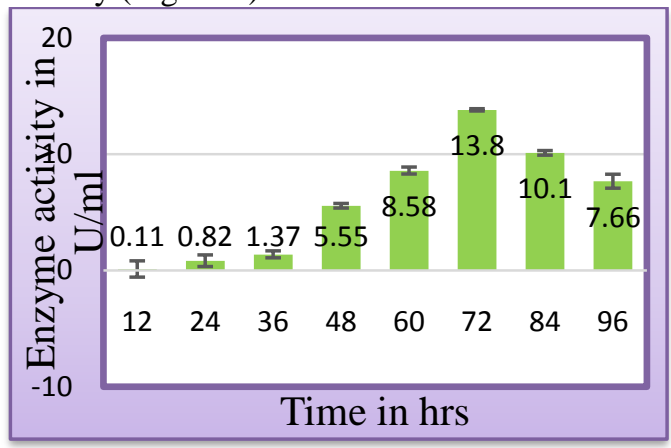

Figure 1.Effect of incubation period on enzyme activity.

Effect of temperature on enzyme production: The result of effect of different incubation temperatures on production of protease by bacterial isolate was shown in Figure 2. The maximum temperature for B.pumilus P1 for biosynthesis of alkaline protease was $45^{\circ} \mathrm{C}$. 


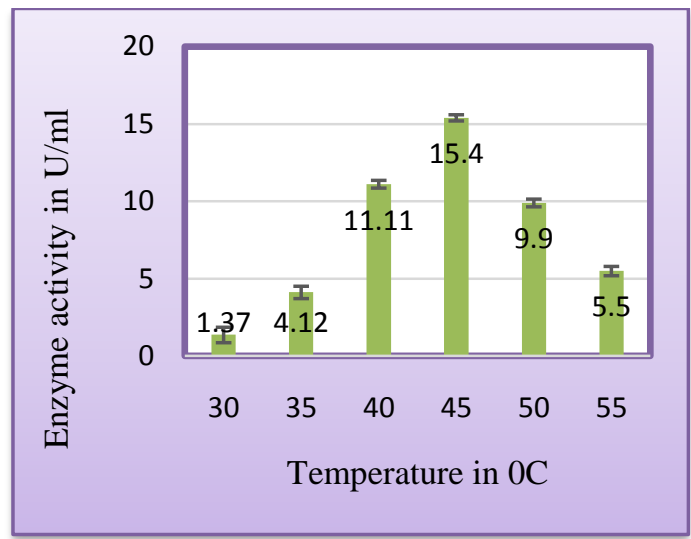

Figure 2.Effect of incubation temperature on enzyme production.

Effect of pH on enzyme production: The optimum $\mathrm{pH}$ at which B.pumillus $\mathrm{p} 1$ showed maximum production is shown in Fig 3. The optimum $\mathrm{pH}$ value for alkaline protease production by B.pumilus $\mathrm{P} 1$ was 8.5.

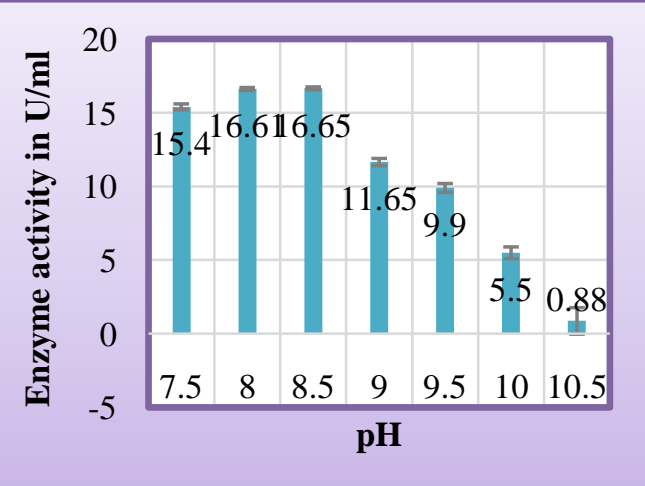

Figure 3. Effect of $\mathrm{pH}$ on enzyme activity on protease production

Optimization using immobilized cells using sodium alginate: The optimum sodium alginate concentration at which B.pumillus p1 showed maximum activity is shown in Fig 4. The optimum sodium alginate concentration value for B.pumilus $\mathrm{P} 1$ was $2.5 \%$.

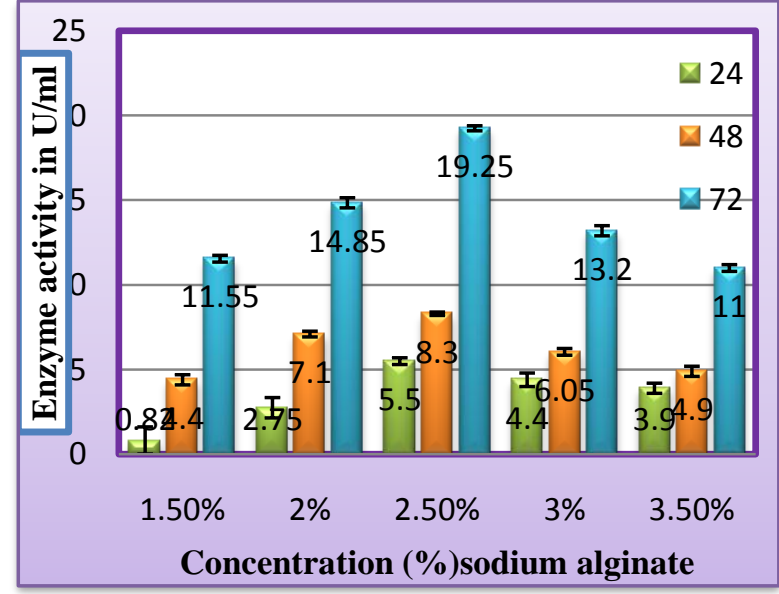

Figure 4.Effect of sodium alginate concentration $(\%)$ on enzyme activity $(\mathrm{U} / \mathrm{ml})$ at different incubation period.

Effect of nitrogen sources on enzyme production: The effect of different refined and crude nitrogen sources shown in figure 5. Among different crude nitrogen sources soyabean meal was excellent in alkaline protease production using B. pumilus $\mathrm{p} 1$ respectively. 


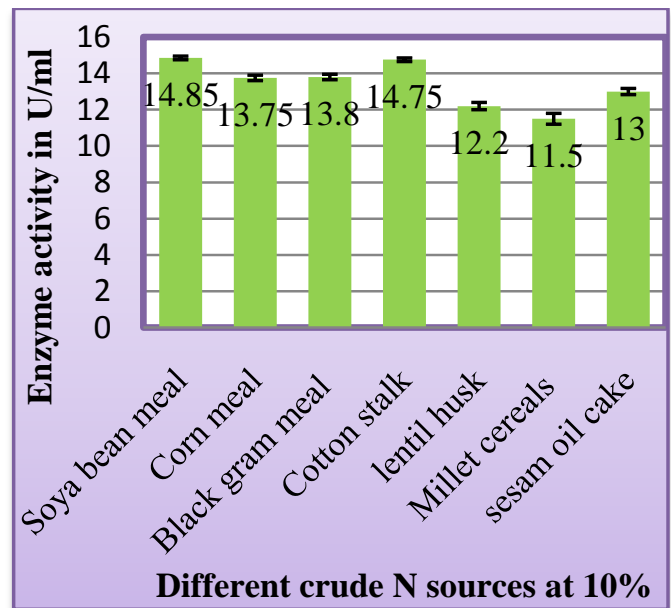

Figure 5. Effect of crude nitrogen sources on alkaline protease production.

Alkaline protease enzyme produced from refined and crude substrates gave $16.5 \mathrm{U} / \mathrm{ml}$ and $8.3 \mathrm{U} / \mathrm{ml}$ enzyme activity respectively as shown in figure 6 .

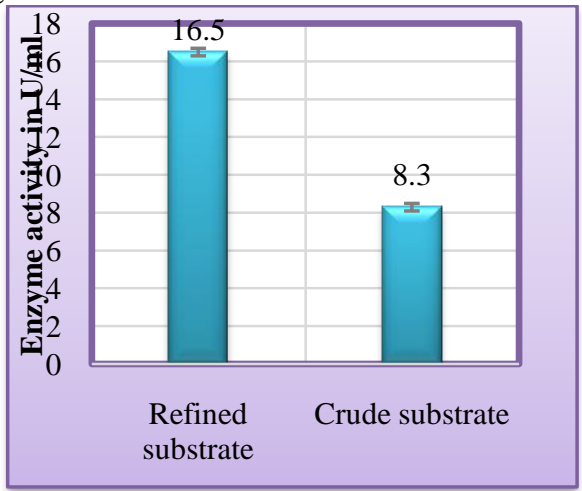

Figure 6. Enzyme activity of crude enzyme extract obtained from refined substrate and crude substrate

Applications: Leather processing: The results of the physical tests showed that the gross evaluation of the finally prepared leather. It had grayish blue color, rough surface, fair stretch ability, too much scud and a normal appearance. (Table 3 and 4) The crude enzymes are efficient in leather processing. The complete depilation was observed in $12 \mathrm{hrs}$.

Table 3. Evaluation of the pelt after treatment with alkaline proteases

\begin{tabular}{|l|l|l|l|}
\hline Experiment & Time of depilation (hrs) & Scud & Pelt colour \\
\hline Treatment 1 & 10 & ++ & White \\
\hline Treatment 2 & 7 & + & White \\
\hline Treatment 3 & 5 & +++ & Blakish \\
\hline
\end{tabular}

Table 4. Evaluation of quality of finally prepared leather treated with alkaline proteases

\begin{tabular}{|l|l|l|l|}
\hline Experiment & Colour & Grain & Scud \\
\hline Treatment 1 & Grey & Smooth & Normal \\
\hline Treatment 2 & Grey & Smooth & Normal \\
\hline Treatment3 & Grey -blue & Rough & Normal \\
\hline
\end{tabular}

Keratin degradation: The B.pumilus $\mathrm{p} 1$ strain was able to grow after 2 days culture in mineral medium containing 30 grams chicken feather as sole source of carbon, nitrogen and sulphur.

Intense feather degrading activity was achieved at $45^{\circ} \mathrm{Cand}$ at $\mathrm{pH} 8$. Nearly complete feather degradation observed at the end of $72 \mathrm{hrs}$ incubation. In contrast no degradation was noted with control.

Furthermore, when chicken feathers were incubated only with purified enzyme total degradation was observed within $24 \mathrm{hrs}$. Therefore, the use of enzymatic and microbiological method for hydrolysis of feather is an attractive alternative to currently used method of feather meal preparation. 


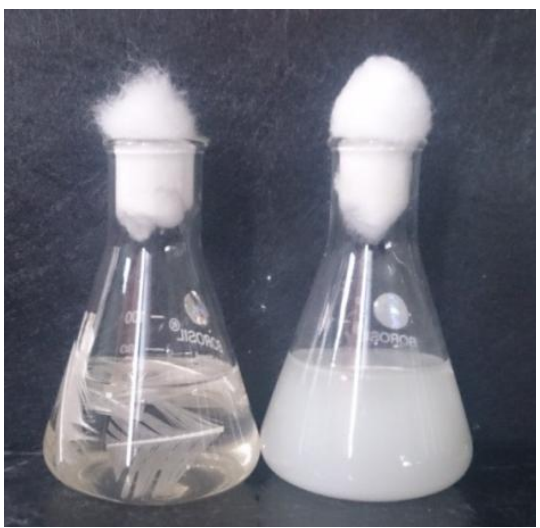

Figure 7. After incubation of feathers with bacterial culture, bacterial utilize feather as carbon and nitrogen sources and show degradation in 24 hrs. Control (left flask), Test (Right flask).

Bio-film degradation: purified enzyme of the isolate B.pumilus p1 was very efficient in removal of bio-film (table 5).

Table -5. Efficiency of purified enzyme in removal of bio-film developed by P.fluroscence and E.coli.

\begin{tabular}{|l|l|l|}
\hline Treatment by enzyme & $P$. fluroscence & E.coli \\
\hline Positive control & 0.35 & 0.37 \\
\hline During incubation & 0.30 & 0.29 \\
\hline After incubation & 0.10 & 0.10 \\
\hline
\end{tabular}

Antifungal activity: The result from the well diffusion technique showed clear inhibition zone of $3.5 \mathrm{~mm}$ diameter, confirmed the antifungal activity of purified protease. The potential of the purified enzyme to inhibit F.solani and R.solani growth in vitro condition indicates that this enzyme may play important role in controlling fungal plant pathogens.

Conclusions: The extracellular alkaline protease producer was isolated screened and identified successfully as B.pumilus. The fermentation conditions were optimized in order to produce maximum alkaline protease with high activity.

The maximum enzyme activity at optimum incubation period, temperature, $\mathrm{pH}$, nutrient availability of refined sources and crude sources was $16.5 \mathrm{U} / \mathrm{ml}$ and $8.3 \mathrm{U} / \mathrm{ml}$ respectively. Enzyme isolated from B.pumilus showed efficient activity in leather processing, keratin degradation, Bio-film removal, and Antifungal agent of fungal plant pathogen. This isolate and purified alkaline protease enzyme may further be exploited for various industrial applications.

\section{Acknowledgement}

Authors are thankful to Bac-test laboratory, Nasik for providing the VITEK-2 system version 05.02 facility for identification.

\section{References}

[1]. Asokan. S. Andjayanthi 2010 Alkaline protease production by bacillus licheniformis and bacillus coagulans. Journal of Cell and Tissue Research Vol. 10(1) 2119-2123

[2]. Bijender Kumar Bajaj. 2013 Thermostable alkaline protease production from Bacillus pumilusD-6 by using agro-residues as substrates. Advances in Enzyme Research Vol.1, No.2, 30-36 (2013)

[3]. Dubey.R, S. Adhikary, J. Kumar and N. Sinha 2010 Isolation, Production, Purification, Assay and Characterization of Alkaline Protease Enzyme from Aspergillus niger and its Compatibility with Commercial Detergents. Developmental Microbiology and Molecular Biology ISSN 0976-5867 Volume 1, Number 1, pp. 75-94.

[4]. Andrew Leslie. 2011 Preventing biofilm formation using microbes and their enzymes. MMG 445 Basic Biotechnologies (2011) 7:6-11 MMG 445.5153325.

[5]. Banerjee.U. 1999 Thermostable alkaline protease from Bacillus brevis and its characterization as a laundry detergent additive. Process Biochemistry 35 (1999) 213-219.

[6]. Devrajillakkiam. Nov 2013 Proteolytic enzyme mediated antagonistic potential against Pseudomonas aerigenosa against macrophomina phasiolina. indian journal of experimental biology.vol 51.pp 1024-1031.

[7]. Sathiya G $\mathbf{2 0 1 3}$ production of protease from bacillus subtilis and its application in leather making process. International Journal of Research in Biotechnology and Biochemistry; 3(1): 7-10

[8]. Gehan M. Abou-Elela1 Hassan A et al .30 may,2011 Alkaline protease production by alkaliphilic marine bacteria isolated from Marsa-Matrouh (Egypt) with special emphasis on Bacillus cereus purified protease. African Journal of Biotechnology Vol. 10(22), pp. 4631-4642.

[9]. FerozKhan (2013) New microbial proteases in leather and detergent industries.Innov. Res. Chem. 1:1 1-6

[10]. Srinubabu G. N.Lokeswari and k. Jayaraju April 2007 Screening of Nutritional Parameters for the Production of Protease from Aspergillus Oryzae. ISSN: 0973-4945; codenecjhao, E-Journal of Chemistry Vol. 4, No. 2, pp 208-215

[11]. Harshada Chandrashekhar Sakpal, Sep - Oct. 2015 Thermostable alkaline protease from Bacillus sp. and its potential applications. IOSR Journal of Pharmacy and Biological Sciences (IOSR-JPBS). Volume 10, Issue 5 Ver. I, PP 58-67, 
[12]. Gizachew Haile Gidamo August, 2009 alkaline protease production by new alkaliphilic microbial isolate under solid state fermentation.

[13]. Bahobil, A. S.et.al. (2011) Production, Purification and Characterization of Alkaline and Thermostable Protease by Shewanella putrefaciens-EGKSA21 Isolated from El-Khorma Governorate KSA. Life Science Journal, Volume 8, Issue 2.

[14]. Lalitha Kumari P. Vijetha, P. Sudhakar 2010 optimization of physico-chemical properties for production of alkaline protease from fusarium graminearum. Recent Research in Science and Technology, 2(4): 24-28 ISSN: 2076-5061

[15]. Anupama P. Pathak 2014 Wealth from waste: Optimized alkaline protease production from agro-industrial residues by Bacillus alcalophilusLW8 and itsbiotechnological applications. sciverse science direct. Journal of Taibah University for Science 8, 307-314.

[16]. Alagarsamy Sumantha1 et al 2006 Rice Bran as a Substrate for Proteolytic Enzyme Production. Brazilian archives of biology and technology.Vol.49, n. 5 : pp. 843-851, September 2006,ISSN 1516-8913

[17]. M. Sankareswaran feb 2014. Optimization of production of an extracellular alkaline protease by soil isolated bacillus species using submerged and solid- state fermentation with agricultural wastes.African journal of microbiology research vol.8(9,pp.872877)

[18]. Vinod Kumar Nigam 2014. Microbial production of alkaline proteases using agricultural by-product. International Journal of Advanced Research ,Volume 2, Issue 6, 407-412

[19]. Mohamed I. El-Khonezy2 015 Partial Purification and Characterization of an Alkaline Serine Protease Produced by Streptomyces griseusNCRRT and its Antifungal Effect on Fusarium solani. World Applied Sciences Journal 33 (5): 831-842,

[20]. Lluvia de Carolina Sánchez-Pérez1 2014, Enzymes of Entomopathogenic Fungi,Advances and Insights, Advances in Enzyme Research, 2, 65-76

[21]. Jayasree D. et al 2009 Optimization of Production Protocol of Alkaline Protease by Streptomyces pulvereceus. Interjri Science and Technology, Vol. 1, Issue 2.

[22]. Jayraman. G. April 2011 Isolation and characterization of a metal ion- dependant alkaline protease from a halotolerant Bacillus aquimaris VITP4.Indian journal of Biochemistry \& biophysics, Vol.48. Pp 95-100

[23]. Shivasharana C.T 2012.Immobilisation of bacillus sp.jb-99 for the production of alkaline protease. International Journal of Recent Scientific Research Vol. 3, Issue, 10, pp.847 -852

[24]. Singhal P 2012 Studies on production, characterization and applications of microbial alkaline proteases. International Journal of Advanced Biotechnology and Research Vol 3, Issue 3, pp 653-669 